\title{
SWOT analysis of China's outward investment in $A S E A N$ 's agricultural industry basing on the perspective of 'One Belt, One Road' initiative
}

\author{
Zhang Lidan \\ International Business School \\ Yunnan University of Finance and Economics \\ Kunming, China \\ 393988476@qq.com
}

\begin{abstract}
The paper is in purpose of clarifying the feasibility and capability of investment in ASEAN's agricultural industry by using SWOT analysis and meanwhile figure out the investment guidance of ASEAN's agricultural industry basing on the perspective of 'One Belt, One Road' initiative.
\end{abstract}

Keywords-China's outward investment; ASEAN, agricultural industry; 'One Belt, One Road' intiative

\section{INTRODUCTION}

2016 is the 25 th anniversary of establishment of dialogue relationship between China and the association of south-east Asian nations (ASEAN). Since China-ASEAN free trade zone (CAFTA) launched in 2010, China has been ASEAN's largest trading partner. In 2015, China and ASEAN are highly pushing the regional integration of Asia- pacific area, and make a consensus on strategic partnership of 'One Belt, One Road' [1].

Agriculture used to play an important role in the ancient Silk Road, and so does in today's 'Silk Road Economic Belt' and the 21st Century Maritime Silk Road'. To follow the 'One Belt, One Road' initiative, China-ASEAN agricultural industry summit 2015 put forward a multilateral exchange of agricultural resources, technology and information among countries in the free trade zone. Specialists of Chinese academy of social sciences believe that China-ASEAN agricultural cooperation could be strengthened by increasing preferential trading policies coming with 'One Belt, One Road' [5].

To make a good use of the friendly political environment, a right choice of agricultural market and trading items should be considered in priority, which is also a tough choice most China's ventures should face. In this sense, the study is in purpose of clarifying the feasibility and capability of investment in ASEAN's agricultural industry by using SWOT analysis, and figure out the investment guidance of ASEAN's agricultural industry afterwards.

\section{FEASIBILITY AND CAPABILITY OF INVESTMENT IN ASEAN'S AGRICULTURAL INDUSTRY}

In past few years, distribution of China's outward capital has heavily tended to agriculture-oriented countries in southeast Asia, such as Vietnam, Laos, Thailand, Cambodia, Myanmar, Indonesia and Philippines. China's previous outward investments of south-east Asian agricultural industry mainly focused on manufacturing, processing and cultivating agricultural products. The openness of China-ASEAN free trade area considerably stimulated multilateral government aids and private collaborations in most border provinces, like Yunnan and Guangxi. However, numerous failure cases of FDI continuously happened in ASEAN market, which implies some negative powers kept adverse working at the same time. To ensure the decision of FDI made in rigorous, objective and comprehensive thoughts, SWOT analysis will be applied then to identify the favorable and unfavorable drivers of exploiting ASEAN's agricultural resources.

\section{A. Strengths of investment in ASEAN's agricultural industry}

The first strength is regarding to geographic adjacent advantage. The early development of outward investment usually follows the principle of proximity. The geographic conditions between China and ASEAN are attractive. China is bordering straight with three countries, Vietnam, Laos and Myanmar. The land borderline is more than 5000 kilometers long, and land ports are intensive in province of Yunnan and Guangxi. In addition, China is neighboring with other countries of ASEAN, and both land transportation and marine traffic are available to link southwest China to Southeast Asia.

The second strength covers several agricultural resources owned by ASEAN. Apart from Singapore, almost all the members of ASEAN are agricultural country in subtropical zone, and agricultural industry output for each is in high proportion of gross domestic production. To be more specific, Southeast Asia is the world's most principle producing area of rice, teak and natural rubber. Thailand, Malaysia and Indonesia's natural rubber productions account for $85 \%$ of their total global output. Other trading items like sugar, 
coconut, hemp, cassava, tobacco, coffee, tropical fruits, tropical flowers and other economic crops are rather frequently exported to the world's market. Moreover, a large amount of arable land resources in Vietnam, Laos, Cambodia, Myanmar, Philippines and Indonesia are still underutilized [2].

Third, a set of China's advanced agricultural technologies were formed with the growth of Chinese rural economy in the period of China's 12th five-year plan. The biggest advantage of China's agricultural science is the hybrid rice technology, which leads a request of technical transfer proposed by Indonesia, Philippines, Malaysia and Vietnam. These three countries are demanding varieties, educational funds and planting technologies from China to fill the gap of agricultural production.

Fourth, low-cost labor is another strong resource in ASEAN. For example, Vietnam's sufficient and cheap labor resources reflects in the fact that $60 \%$ percentage of total population are people under 27 years old, and monthly pay of its labor force are averagely ranging from 45 to 55 dollars [3]. The cost advantage of human resource appeals to a lot of labor-intensive corporation from China, whose success is tightly depend on cost leadership.

The fifth strong point is the strong social resources occupied by China's people overseas. According to demographic statistics, there are 30 million Chinese residents in south-east Asia, and most of them keep strong ties with motherland. They show a strong willingness to be intermediary agent of liberal business.

\section{B. Weaknesses of investment in ASEAN's agricultural industry}

The similarity of natural endowment will intensify the competition instead of collaboration. Some agricultural products from China and ASEAN are too homogeneous to make possible exchange. Eight out of China's top ten exporting items are as well in the exporting list of Thailand and Indonesia. China's productivity and market price of litchi, banana, mango and pineapple are inferior to some countries in ASEAN, which will be more likely to lead the multilateral competitions and conflicts for market share.

The second defect is the weak quality of labor force in ASEAN. There are less than $13.24 \%$ Vietnam people have education background higher than undergraduate level [4]. Hence, many China's enterprises complained that local labor market is in great shortage of agricultural professionals of engineers, agronomists and animal husbandry. The unstable and unsatisfied supplies of labors limits China's investment to few technology contained activities. Basing on the low-level workforces, the implementation of optimizing structure and upgrading technology of ASEAN's agriculture should take a long-term view.

The third obstacle of FDI is the shortage of main driver to carry multinational business forward. The current domestic venture of ASEAN's agricultural business are still in small scale and lack of competiveness. It is unlikely to shape the industrial cluster and gain the benefits from economies of scale. Moreover, China's cross-border agricultural cooperation programs still mainly rely on state-owned corporations, and private capitals are seldom participating in. Private investors with few enthusiasm and confidence to develop abroad business in ASEAN are mainly due to their inadequate knowledge and experiences of negotiating and interacting with ASEAN's side. The limitation of ASEAN's agricultural market information and agricultural funds result in the great probability of suffering investment risk and failure On one hand, the incomplete regulation of overseas investment loans, guarantee and insurance, the restriction of examination and approval of foreign investment, and inefficiency of tax rebates could easily frustrate private trader's motivation. On the other hand, Chinese authority's unclear statement of protection measures and unattractive preferential policies for outward investors might lose private capital's involvement from a great extent.

Forth, domestic delivery of talents is either questionable. Although China's academic institutions have several educational programs of minority language, there are small number of talents with competence of using minority language, ASEAN laws, and knowledge of international trade and investment. For people already working in ASEAN free trade zone, part of them are heavily unfamiliar with local business laws and regulations, plagued by mismatching knowledge structure and unfriendly workplace. In this case, an increasing amount of talents request of return or even resign. For most domestic investor, the unstable and inefficient talent transfer becomes an important problem of ASEAN's agricultural investment.

The shortage of information resource can be the fifth difficulty of doing business in ASEAN. The majority of China's enterprise have a weak access to ASEAN market information, including agricultural development prospects, market capacity, agriculture legal system and administrative procedure. Without deep understanding of host country's investment environment, it makes no sense to have timely and correct investing decisions. China's investors has realized the necessity of information exchange, but only small number of them make actions to establish and expand their information channels in their foreign branch. The large part of domestic venture still keep no interactions with ASEAN's customers, clients, suppliers, wholesalers, retailers and agents because of weak communication intermediary. Accordingly, there is no way of doing market research and development for these entities.

The last drawback of investment in ASEAN's agricultural industry is the financing troubles. The outward investment requires much more funds than domestic venture, since FDI should spend more on establishment of distribution network, advisement, certification of intellectual property, and extension of local social connections. The fact is that most small and medium enterprises cannot finance the new venture by their own, but ask external capital support from financial institutions. However, new venture in ASEAN market are some more likely to be rejected by financial institutions, with a consideration of the uncertainty of return on investment and high risk of overseas venture on agricultural production. Except for policy bank, agricultural enterprises can rarely get 
fund from business banks, and this will largely reduce the feasibility of investment in ASEAN agricultural industry.

\section{Opportunities of investment in ASEAN's agricultural industry}

In terms of positive external impacts, there are several ASEAN's policies and regulations beneficial to agricultural investment. Also, some project of optimizing foreign investment environment has been increasingly implemented. Most south-east Asian nations adopted policies like reduction or exemption of tax, loosen control of foreign exchange, and ease restrictions on merger and acquisition for foreign investors. Vietnam authority circled the special zone for foreign investment, in which investors will be rewarded with free land rent, free land royalties and free land tax of occupancy. In the sight of domestic governance, the act of investment in ASEAN is being encouraged all along. China's favorable measures were getting focused when CAFTA was established. In 2002, bilateral authorities signed a memorandum of understanding the agricultural cooperation between China and ASEAN. The file defined the main areas of cooperation in the field of agriculture. In 2016, 'One Belt, One Road' initiative states five visions of China- ASEAN agricultural cooperation, including policy intercommunication, facility union, trade openness, mutual finance support and cultural combination.

The second opportunity seems to be prosperity of agricultural economy in both China and ASEAN. According to the report of IMF, nations of south-east Asia are stepping towards a higher level of economy growth, targeting 5\% increase in average [5]. It provides a stable base for sustainable development of agriculture. Second, agriculture is considered as the main driving force of GDP in most districts of ASEAN, and thus heavier government budget of ASEAN will be allocated to its related industries.

\section{Threats of investment in ASEAN's agricultural industry}

The most miserable trouble for China's investments in ASEAN is the tough interferences from Japan and Korea. Japan is confident with its influences on ASEAN's international business. Japan has involved in ASEAN's material export and FDI at the earliest, and historically been the largest foreign investors of ASEAN in 1990s. Following this, Japan was negotiating with members of ASEAN to achieve the free trade agreement in 2003 and express the high enthusiasm to establish Japan-ASEAN free trade zone against CAFTA. China's second largest rivalry in ASEAN is Korea. In 2009, Korea and ASEAN completed preferential agreement on goods, service, investment and dispute settlement. Either Japan or Korea has achieved a high level of agricultural modernization, and occupied a large percentage of agricultural market shares in ASEAN. Obviously, Japan and Korea's threats to China's FDI in south-east Asia will be deepen because of their closer political ties with ASEAN [6].

The second risk of FDI in ASEAN results from the uncertainty and complexity of transitional investment. Exchange rate risk is one of the most common negative drivers, since CAFTA should settle the exchange of eleven currencies issued by different countries. The frequent foreign exchange settlement means any fluctuation of exchange rate of free trade zone might produce a possible loss to transnational investors. Despite of foreign exchange risk, emergencies like war, political instability, expropriation, culture conflicts and default risk of host country will all damage the safety and benefits of foreign stakeholders.

Another potential crisis is the recovery of trade protectionism with the downside of world economy in recent years. The financial crisis has seriously brought about a reduction of agricultural productivity and the collapse of huge numbers of companies, especially for export-driven agricultural enterprises. Because of weakened demand of international agricultural market, the domestic suppliers of agricultural products encounter the poor sales and price down, which has deeply damaged the behalf of agricultural producers. The downward trend of price is continuing and makes the outward investment of agricultural industry blocked. Increasing risks of new venture on agriculture will hit China's confidence of outward investment in ASEAN's agricultural industry

\section{SUGGESTIONS}

According to above SWOT analysis of investment environment in ASEAN agricultural industry, China's outward investment in this area is worthwhile and feasible in spite of some drawbacks. China's investor should prioritize the investment program with high market potential, favorable political environment, full performance of local resource endowment, and great demand of China's technological delivery.

To exploit the $\mathrm{S}$ and $\mathrm{O}$, and avoid or mitigate the $\mathrm{W}$ and $\mathrm{T}$, the study speculates some suggestions that could fit these situations, and these findings could be a reasonable guidance to China's further investment in ASEAN.

First, China might utilize bilateral complementarities in agriculture to strengthen the collaboration between China and ASEAN. The favorable structure of outward investment in ASEAN consists of six fields, including food planting (grain and economic crops), forestry of medicinal plants and forest, supportive agricultural service (machinery, pesticides, fertilizer and feed) rural energy.

For food planting, China's Index of Revealed Comparative Advantage (RCA) is higher than ASEANs. RCA of China's grain products is in range of $1.4 \sim 2.0$, while ASEANs average level is around $1 \sim 1.2$ [7]. China's comparative advantage is more obvious in rice planting, and it could be an promising option in places like Philippines, Indonesia, Malaysia where the import of rice is always In urgent need. To some degree, food planting are mutually complementary between China and ASEAN members. China's products of temperate zone are truly deficient ones for most ASEAN countries, and meanwhile China is short of ASEAN's tropical products such as palm oil, cocoa and cashew nut. In terms of economic crops, Philippines, Malaysia, Thailand is encouraging foreign capital to tropical economic crops like palm oil and rubber. China is rightly in 
huge demand of these two economic crops as raw inputs for processing and manufacturing activities.

With regard to forestry of medicinal plants and forest, mutual benefits can be reached in several ways. On one hand, China can adopt the form of land lease to exploit Myanmar and Laos' forest resource in wood production and processing. On the other hand, China could encourage home enterprises in strong capital condition to purchase or rent forest land among neighboring countries so as to develop litchi, longan, citrus and tropical fruits in large scale.

In terms of supportive agricultural service and rural energy, China could firstly focus on service with quick turnover, such as machinery, pesticides, fertilizer and feed. Then China might generalize rural energy like household biogas in ASEAN's rural areas. Either agricultural machinery or household biogas is the best example of technology transfer. In this case, China's investor should localize the technology of agricultural machinery and make some adjustment according to the local climate situations. Household biogas, as an successful green technology applied in sustainable agricultural development, can be utilized in ASEAN countries to optimize the local use of kitchen as well as toilet. It can be seen that supportive agricultural service and household biogas could respectively improve the mode of production and living standard for rural residents.

Second, China might push the transformation of agricultural industry, using the innovative achievement of domestic university and research institutions. With the upgrading of industrial technology, products, and the supply chain, the agricultural resources could be restructured and transformed to be the new competiveness. For enterprises with single product, it would be better to enlarge the business scope, by either vertical integration or horizontal integration.

Third, China should deepen strategic partnership with Asian countries by giving full play of the geographical advantages. Large border region with neighboring countries like Myanmar, Laos, Vietnam makes it more convenient for China's southwest cities to actively increase multilateral social interactions and economic exchanges.
To address the threats from other business rivalry, peopleto-people diplomacy could be the best way to frustrate Japan and Korea's closer political ties with ASEAN. In other words, people who engage in the transnational business and people live close to the border will be the intermediaries to keep China-ASEAN relationship closer, and China could take the geographical advantages to make it true.

Considering the entry timing, 'One Belt, One Road' initiative can be the best channel for China to speed up investment of these fields, and achieve a better market position in south-east Asia.

\section{ACKNOWLEDGMENT}

On the completion of this study, I should like to express my deepest gratitude to all those, whose kindness and advice have made this work possible. I am greatly indebted to my advisor Yin Hao who gave me valuable instructions and constructive suggestions.

\section{REFERENCES}

[1] G.H. Tan, Y.Q. Zhang, W. Zhang, and S. Liang, “ 'One Belt, One Road' initiative makes a progress of China-ASEAN agricultural cooperation," Xinhua News, 2015.

[2] J.J. Cheng, and C.M. Xiao, "Study on China-ASEAN trade complementarities," World economy study, vol. 8, 2012, pp. 22-28.

[3] S.X. Tang, "China-ASEAN's strategic choices of agricultural cooperation," World agriculture, vol. 12, 2008, pp. 3-6.

[4] X.Y. Li, and J.W. Guan, "Assessment of China-ASEAN's agricultural cooperation," Knowledge economy, vol. 11, 2011, pp. 164-165.

[5] Y.H. Zhang, "Opportunities and measures of China's participation in overseas agricultural investment," Development study, vol. 9, 2009, pp. 50-52.

[6] M.F. Xu, "China's strategy of outward investment in agriculture,"China cooperation economy, vol. 10, 2011, pp. 47-48.

[7] L. Yang and Y. Lv, "Study on the impact factors of China ASEAN agricultural trade," Resource science, vol. 31, 2009, pp. 1654-1661. 